\title{
Desnacionalização e financeirização: um estudo sobre as privatizações brasileiras (de Collor ao primeiro governo FHC) *
}

\author{
Carlos Henrique Lopes Rodrigues ${ }^{* *},{ }^{* * *}$ \\ Vanessa Follmann Jurgenfeld ${ }^{* * * *}$
}

\section{Resumo}

Este artigo discute as principais privatizações realizadas pelos governos Collor, Itamar e FHC. Esses processos, voltados a atender prioritariamente os interesses do capital oligopolista privado estrangeiro, conduziram a uma importante desnacionalização e financeirização da economia brasileira. Na primeira parte, o artigo debate as políticas econômicas neoliberais do país nos anos 1990, que resultaram na venda de estatais a preços baixos e em processos de lisura duvidosa. Na segunda parte, são discutidas as mudanças nos marcos legais e a desestatização de empresas selecionadas (Usiminas; CST; CSN; PQU; Embraer; Telebrás; CVRD e Light), a partir de documentos do BNDES, leis, decretos e artigos da imprensa.

Palavras-chave: Privatização; Neoliberalismo; Desnacionalização.

\begin{abstract}
Denationalization and financialization: a study on Brazilian privatization (from the Collor government to FHC's first term)

This article discusses the main privatizations that took place during the Collor, Itamar and FHC governments. Primarily meeting the international oligopolistic capital objectives, the privatizations resulted in the denationalization of the Brazilian economy and improved financialization. Firstly, the article debates the neoliberal policies in Brazil during the 1990's that resulted in the selling of state companies at lower prices in some suspicious auctions. Secondly, it discusses the changes in the legal framework and to a number of privatized companies (Usiminas; CST; CSN; PQU; Embraer; Telebrás; CVRD e Light), based on BNDES documents, laws, decrees and newspapers.
\end{abstract}

Keywords: Privatization; Neoliberalism; Denationalization.

JEL O10, O14, O20.

\section{As privatizações no Brasil na fase da internacionalização financeira mundial}

A internacionalização financeira é caracterizada basicamente pelo período histórico em que a dimensão financeira do capital estabelece uma dinâmica crescente em relação à dimensão

\footnotetext{
* Artigo recebido em 4 de maio de 2017 e aprovado em 13 de agosto de 2018.

** Professor do Curso de Ciências Econômicas da Universidade Federal dos Vales do Jequitinhonha e Mucuri (UFVJM), Teófilo Otoni, MG, Brasil.

${ }^{* * *}$ Coordenador do Grupo de Estudos em Desenvolvimento Econômico Brasileiro da Universidade Federal dos Vales do Jequitinhonha e Mucuri (Gedeb/UFVJM), Teófilo Otoni, MG, Brasil. E-mail: chlrodrigues@ yahoo.com.br.

${ }^{* * * *}$ Professora do Curso de Ciências Econômicas da Universidade Federal dos Vales do Jequitinhonha e Mucuri (UFVJM), Teófilo Otoni, MG, Brasil. E-mail: vfollmann@hotmail.com.
} 
produtiva $^{1}$. Este movimento, iniciado em meados dos anos 60 , exacerba-se principalmente a partir dos anos 1970 no capitalismo mundial. Levadas ao extremo, as operações financeiras atingem "o mais alto grau de mobilidade, [de forma que se torna] mais gritante a defasagem entre as prioridades dos operadores e as necessidades mundiais" (Chesnais, 1996, p. 239).

Condutoras em grande medida deste processo, as empresas multinacionais passam a partir deste período a ter seus investimentos orientados muito mais aos retornos do rentismo, de forma que "os grupos industriais [transformam-se em], propriamente, grupos financeiros de predominância industrial [...], se tornam organizações cujos interesses identificam-se sempre mais com os das instituições estritamente financeiras" (Chesnais, 1996, p. 275-276).

Com o grande desenvolvimento da esfera financeira, nos anos 1980 e 1990 já era possível constatar um aumento maior dos ativos financeiros em relação aos investimentos em capital fixo. "Em 1992, os ativos [financeiros] acumulados eram o dobro do PNB acumulado de todos os países da OCDE juntos, e treze vezes mais do que suas exportações totais" (Chesnais, 1996, p. 244).

$\mathrm{Na}$ periferia do capitalismo, as novas estratégias de acumulação das empresas multinacionais as levaram ao investimento especulativo em ativos financeiros e à compra de empresas estatais de setores-chave da economia, ofertadas a preços baixos. Nos anos $1980 \mathrm{e}$, sobretudo nos anos 1990, é quando a financeirização na periferia aumenta. Isso porque na segunda metade da década de 1980 os Estados Unidos reduziram sua taxa de juros, que estava em torno de 20\%, "para 4,5\% no mercado monetário de Nova Iorque, [verificando-se] uma aceleração do crescimento e da globalização ${ }^{2}$ dos mercados futuros de juros e câmbio, com saída de fundos de pensão norte-americanos em busca dos chamados "mercados emergentes" (Tavares; Melin, 1997, p. 61). No caso do Brasil, a procura desses fundos direcionou-se às privatizações e à aquisição de títulos da dívida pública após o país fazer mudanças na área econômica exigidas pelos interesses de acumulação privada, notadamente aderindo às regras estabelecidas pelo Consenso de Washington ${ }^{3}$.

Para receber esses "investimentos", o Brasil realizou a abertura comercial, produtiva e financeira, além de implantar uma política econômica com estabilidade de preços ${ }^{4}$. Nesse novo movimento do capital, o país teria seu balanço de pagamentos "fechado" com os "investimentos financeiros" que eram defendidos pelos governos no discurso de que trariam

(1) Deve-se ressaltar que os investimentos financeiros se apropriam da riqueza produzida no setor produtivo. "A esfera financeira nutre-se da riqueza criada pelo investimento e mobilização de uma força de trabalho de múltiplas qualificações. Uma parte, hoje elevada, dessa riqueza é captada ou canalizada em proveito da esfera financeira, e transferida para esta" (Chesnais, 1996, p. 246). Para o entendimento do período da internacionalização financeira também recomenda-se Campos (2009).

(2) Ver Gonçalves (1999).

(3) Sobre Consenso de Washington, ver Batista (1994).

(4) A transferência de riqueza da esfera produtiva para a esfera financeira fez com que o foco "da política econômica de muitos governos, não apenas da periferia como também do coração do sistema, [fosse] o pagamento dos juros e do principal das dívidas públicas e a garantia de juros reais positivas, implementando políticas sob a égide do combate à inflação" (Chesnais, 1995, p. 22). 
Desnacionalização e financeirização: um estudo sobre as privatizações brasileiras...

um suposto desenvolvimento econômico. A abertura financeira estimulou a entrada desses capitais especulativos e também funcionou no sentido de permitir a aquisição de setores produtivos e de serviços estratégicos (como siderurgia, mineração, petroquímica, transportes, energia e telecomunicações), até então nas mãos do Estado, e que passavam a ser de interesse do capital privado internacional pela busca, sobretudo, de matérias-primas em todo o globo para fomento da sua expansão mundial, e como forma de amenizar a sua sobreacumulação. Segundo Harvey (2003), quanto mais o capital se encontra sobreacumulado, maior a interferência imperialista para tentar solucionar essa situação. O neoliberalismo, de acordo com ele, surge nos anos 1970 justamente como uma resposta à sobreacumulação, sendo as privatizações parte de um mecanismo para proporcionar lucros para esse capital, em um processo liderado pelo imperialismo norte-americano e que Harvey (2003, p. 124) denominou "acumulação por espoliação": "O que a acumulação por espoliação faz é liberar um conjunto de ativos [...]. O capital sobreacumulado pode apossar-se desses ativos e dar-lhes imediatamente um uso lucrativo".

A privatização abriu amplos campos a serem apropriados pelo capital sobreacumulado na periferia ${ }^{5}$, e em especial, no Brasil. Realizada muitas vezes às pressas, com preço e condições de pagamento atrativas para o capital privado ${ }^{6}$, a desestatização em massa levou o Brasil a uma redução significativa de sua Formação Bruta de Capital Fixo (FBCF), um processo que causou uma importante desindustrialização ${ }^{7}$ no país, não revertida desde então. As privatizações impulsionaram a desnacionalização da economia, com parte das ações das empresas estatais sendo comprada por estrangeiros, e induziram a uma financeirização exacerbada, uma vez que bancos de investimentos e outras instituições financeiras, como fundos de pensão, foram protagonistas entre os adquirentes nos leilões. Em vários casos, poucos anos após comprar ações dessas empresas, as instituições financeiras as revenderam, confirmando seus objetivos puramente especulativos com a rápida saída do negócio, após aferição de retornos significativos ${ }^{8}$.

(5) Destaca-se que marcaram as mudanças dos países periféricos em geral para ter acesso ao novo ciclo de internacionalização de capital a Rodada Uruguai (1986 a 1994), que resultou posteriormente na criação da Organização Mundial do Comércio (OMC), a cartilha do Consenso de Washington e a renegociação da dívida externa por meio do Plano Brady, além do Mercosul. Sobre a OMC, ver Campos (2009). Sobre o Consenso de Washington, ver Batista (1994). Em relação ao Plano Brady, ver Batista Jr.; Rangel (1994). Sobre o Mercosul, ver Sarti (2001).

(6) Um exemplo dessas facilidades vem do BNDES, que muitas vezes financiava a compra das empresas, além de oferecer financiamentos para o comprador posteriormente.

(7) Sobre desindustrialização, consulte Cano (2012).

(8) Entre as vendas lucrativas realizadas por bancos destacam-se as saídas em 1996 do Bozano, Simonsen e do Unibanco da Acesita, privatizada quatro anos antes. Os dois bancos tiveram ganho bruto de R $\$ 500$ milhões na negociação de suas participações na empresa (Bancos..., 25 abr. 1996, p. A1; C1). Também destacam-se as ofertas recebidas pelo banco Pactual por sua participação na Escelsa, empresa de energia do Espírito Santo, privatizada em 1995. Dois anos depois da desestatização o presidente do banco, Luiz Cesar Fernandez, ressaltava: "Sou vendedor e já recusei ofertas de 100\% sobre o preço do mercado dos papeis" (Pactual..., 25 nov. 1997, p. C3). A declaração mostra quão lucrativo foi o negócio em dois anos e o alto volume de interessados, a ponto de Fernandez recusar um lucro superior a $100 \%$. 
Carlos Henrique Lopes Rodrigues, Vanessa Follmann Jurgenfeld

Algumas das mudanças sugeridas pelo Consenso de Washington, como abertura comercial, produtiva e financeira, privatizações a partir da criação do I Plano Nacional de Desestatização (I PND) e uma tentativa de estabilização dos preços da economia brasileira, ocorreram após Fernando Collor de Mello assumir a presidência em 1990 e implantar o Plano Collor. Ele, no entanto, não conseguiu a estabilidade de preços e as dificuldades na composição de forças políticas aliadas fizeram com que sofresse um processo de impeachment e deixasse a presidência da República em dezembro de 1992.

O vice Itamar Franco assumiu a presidência após a sua saída e Fernando Henrique Cardoso (FHC) foi chamado para ser o novo Ministro da Fazenda (deixando o cargo de Ministro das Relações Exteriores) e levar adiante as políticas econômicas consubstanciadas no Consenso. Ainda que Itamar não tenha rompido com o neoliberalismo de Collor, foi, no entanto, no governo de FHC que este ganhou força no país e se consolidou.

No governo FHC, houve o acirramento da abertura econômica, uma perda ainda maior de autonomia por parte do Estado com os desdobramentos do Plano Brady, a estabilização de preços com a implementação do Plano Real, que havia sido elaborado ainda no governo de Itamar, e o avanço das privatizações por meio do II Plano Nacional de Desestatização (II PND).

O Plano Real ${ }^{9}$, cujo êxito no combate à inflação mostrava-se central para projetar FHC em sua reeleição, resultava de uma exigência internacional, dado que o afluxo de capital financeiro que começaria a emergir principalmente na década de 1990 requereria, para continuar seu movimento aos países periféricos, desregulamentação financeira e estabilidade econômica. Planos econômicos de estabilização de preços foram colocados em prática em vários países com elevados processos inflacionários principalmente a parir da década de 1980 . No Brasil não foi diferente.

Como na fase da internacionalização financeira a estabilidade econômica tornou-se um pressuposto para que os países conseguissem atrair fluxos de capitais disponíveis no mercado financeiro mundial, o Plano Real e o então Ministro da Fazenda contaram com o apoio do Fundo Monetário Internacional (FMI), das empresas multinacionais e da burguesia brasileira. Esta última manifestou-se em documento da Federação das Indústrias do Estado de São Paulo (Fiesp), em 1990, intitulado "Livres para Crescer", no qual sinalizava seu anseio de também tirar vantagens dos ganhos da financeirização em detrimento do setor produtivo industrial ${ }^{10}$ (Fiesp, 1990).

(9) O Plano Real foi implementado em 3 fases. Sobre o Plano Real, ver Oliveira (1996) e Filgueiras (2006).

(10) Ver Deo (2005). 
Desnacionalização e financeirização: um estudo sobre as privatizações brasileiras...

Para manter a estabilidade do plano, foi adotada uma taxa de juros elevada para atrair o capital financeiro internacional. Isso resultou em uma moeda nacional valorizada, de modo que o governo realizaria intervenções no mercado ofertando títulos da dívida pública diariamente. A política econômica promovia, assim, uma excessiva emissão de títulos remunerados a uma extraordinária taxa de juros que conduzia a um aumento expressivo da dívida pública brasileira. "O estoque de títulos públicos sob responsabilidade da União saltou de R \$ 62 bilhões no final de 1994 para um patamar superior a R \$ 674 bilhões em agosto de 2002 (sendo mais de 1/3 deste total atrelado à variação cambial)" (Sampaio Jr., 2007, p. 299). Além do endividamento público interno, houve crescimento do endividamento externo, porque o governo também era obrigado a contrair empréstimos por meio de pacotes do FMI, principalmente quando havia algum abalo na Bolsa de Valores dos países "emergentes" e o especulador ameaçava sair desse mercado.

Com esta forma de operar, o Plano Real criou uma armadilha ao crescimento econômico, visto que quando a economia crescia, elevavam-se ainda mais os déficits comercial e de transações correntes. Isso ocorria porque a moeda sobrevalorizada e a abertura comercial rebatiam negativamente em uma das principais contas até então superavitárias - a balança comercial -, que passaria a apresentar vultosos déficits a partir de 1995. Como em um círculo vicioso, o governo "resolvia" o problema com a emissão de títulos da dívida pública, que aumentava de forma significativa para manter a moeda artificialmente valorizada e para "fechar" o balanço de pagamentos, mais dependente da entrada de capital estrangeiro.

Com o aumento da dependência e da vulnerabilidade externas do país, escancaradas pelo Plano Real, o governo brasileiro acirrou o processo de privatização, tido também como funcional para o equilíbrio fiscal. O governo tentava com os leilões de desestatização recompor as reservas cambiais a fim de manter o real valorizado ${ }^{11}$. A melhora do perfil da dívida pública, o discurso da modernização do parque produtivo e dos excessos da participação do Estado na economia eram evocados para justificar as privatizações. Tratou-se da defesa do Estado mínimo e do mercado livre ${ }^{12}$.

(11) É importante lembrar que FHC manteve o real valorizado até sua reeleição e no primeiro mês de seu segundo mandato, em 1998, já promoveu uma forte desvalorização da moeda na tentativa de reduzir os déficits em transações correntes e a fuga de capitais foi minorada com empréstimos por parte do FMI e a exigência de metas de inflação, câmbio flexível e superávit primário. Essa política ficou conhecida como tripé macroeconômico.

(12) Ressalta-se que a privatização estava entre os dez pontos elencados no Consenso de Washington, que foram: "1) disciplina fiscal; 2) priorização dos gastos públicos; 3) reforma tributária; 4) liberalização financeira; 5) regime cambial; 6) liberalização comercial; 7) investimento direto estrangeiro; 8) privatização; 9) desregulação; e 10) propriedade intelectual" (Batista, 1994, p. 18). 
Carlos Henrique Lopes Rodrigues, Vanessa Follmann Jurgenfeld

\section{As mudanças nos marcos legais para a desestatização e as principais privatizações dos $\operatorname{anos} 1990$}

\subsection{Governo Collor}

As empresas estatais do setor de infraestrutura foram o principal foco das privatizações de Collor. Como marco legal desse processo, por meio da Lei n. 8.031, de 12 de abril de $1990^{13}$ houve a criação do I PND. Preso à retórica neoliberal de que o Estado só deveria investir em empresas e setores que não fossem do interesse do capital privado, o governo argumentava que direcionava as suas atenções para aquilo que ele entendia como "atividades essenciais". De maneira vaga, as atividades consideradas estratégicas e de responsabilidade direta do governo se relacionavam à "educação, saúde, bem-estar social e qualidade de vida" (Programa..., 1992, p. 2).

As diretrizes da Lei n. 8.031 iam ao encontro das propostas do Consenso de Washington, uma vez que o I PND explicitava o seu propósito de transferir para a iniciativa privada as empresas estatais para diminuir a presença do Estado na economia. Essa lei estabelecia ainda um limite à participação do capital estrangeiro nos leilões de $40 \%$ e determinava uma participação máxima, em caráter excepcional, de 15\% para compra de ações de uma empresa estatal por outra estatal.

Nos primeiros processos de privatização do governo Collor, no ano de 1991, chamava a atenção o alto volume de medidas judiciais, no total 27, que denunciavam as suas incorreções, dentre as quais estavam ilegalidades no edital e subavaliação. O conjunto de empresas estatais inclusas no I PND envolvia os setores de siderurgia, petroquímica e fertilizantes, porque estes eram considerados pela Constituição como "áreas livres"14, ou seja, passíveis de serem transferidos para o setor privado.

As privatizações efetuadas pelo governo Collor totalizaram 18 empresas. As vendas somaram US\$ 3,6 bilhões (Tabela 1).

(13) A Lei 8.031 considerava privatização "a alienação, pela União, de direitos que lhe assegurem, diretamente ou através de outras controladas, preponderância nas deliberações sociais e o poder de eleger a maioria dos administradores da sociedade". Disponível em: http://www2.camara.leg.br/legin/fed/lei/1990/lei-8031-12-abril-1990-375980-publicacaooriginal-1-pl.html.

(14) As divisões se davam da seguinte maneira: "1) Áreas de Monopólio: prospecção, refino e transporte de petróleo e gás natural: PETROBRÁS; 2) Áreas de Concessão Estatal: serviços públicos que podem ser realizados por concessão exclusivamente empresa de capital estatal. Serviços telefônicos, telegráficos e de transmissão de dados: TELEBRÁS; 3) Áreas de Livre Concessão: serviços públicos que podem ser realizados sob concessão a agentes privados: energia elétrica: ELETROBRÁS, portos: PORTOBRÁS, ferrovias: RFFSA, águas e esgotos, infraestrutura aeroportuária e rodovias interestaduais; e 4) Área livre: demais empresas industriais e de serviços em geral: SIDERURGIA, PETROQUíMICA, MINERAÇÃO e outros" (Prado, 1994, p. 102, grifos do autor). 
Desnacionalização e financeirização: um estudo sobre as privatizações brasileiras...

Tabela 1

Privatizações do governo Collor

\begin{tabular}{l|c}
\hline Empresa privatizada & Valor da venda (em US\$ milhões) \\
\hline Usiminas & $1.112,40$ \\
\hline Companhia Petroquímica do Sul (Copesul) & 797,1 \\
\hline Cia Aços Especiais Itabira (Acesita) & 465,4 \\
\hline Companhia Siderúrgica de Tubarão (CST) & 347,4 \\
\hline Petroflex Ind. e Com. S.A. & 234,1 \\
\hline Fertilizantes Fosfatados (Fosfértil) & 182 \\
\hline Aços Finos Piratini S.A. & 107,9 \\
\hline Celma & 90,7 \\
\hline Companhia Nacional de Álcalis (CNA) & 81,4 \\
\hline Companhia Industrial de Polipropileno (PPH) & 59,4 \\
\hline Polisul Petroquímica S.A. & 56,8 \\
\hline Marfesa & 48,4 \\
\hline Nitriflex S.A. Ind. e Com. & 26,2 \\
\hline Cosinor & 13,7 \\
\hline Goiás Fertilizantes S.A. (Goiasfértil) & 13 \\
\hline Serviço de Navegação da Bacia do Prata & 12 \\
\hline SNBP) & 10,9 \\
\hline Companhia Brasileira de Estireno (CBE) & 6,8 \\
\hline Indag S.A. & $3.665,6$ \\
\hline Total & \\
\hline Fonte: Progrma..(1992 1993.Elat & \\
\hline
\end{tabular}

Fonte: Programa... (1992, 1993. Elaboração própria).

\subsubsection{O caso Usiminas}

A venda da Usiminas, por US\$1,1 bilhão ${ }^{15}$, foi a maior em valor feita entre $1991 \mathrm{e}$ 1992. A empresa era reconhecida pelo governo Collor como "uma das mais eficientes em termos mundiais" (Programa..., 1992, p. 49). Antes do leilão, as ações da Usiminas dividiamse entre: Siderbrás/BNDES (85,3\%), BNDES/opções minoritárias (9,4\%), Nippon-Usiminas $(5,0 \%)$ e outros acionistas antigos $(0,3 \%)$. Ao fim do processo de alienação, o controle acionário da Usiminas ficou distribuído conforme Gráfico $1^{16}$.

(15) O preço final da Usiminas chegou a US\$ 1,3 bilhão, em razão da venda posterior de ações remanescentes.

(16) Essa composição acionária não durou muito tempo. Alguns anos depois de ser privatizada, alguns acionistas deixaram a empresa e seus papéis foram adquiridos por aqueles que já faziam parte do seu quadro acionário. Uma cláusula estabelecida no acordo de acionistas permitia, por exemplo, que quando o banco Bozano, Simonsen (detentor em 1996 de 6,68\% das ações) saísse da empresa, os demais poderiam adquirir seus papéis e outros poderiam vir a ser convidados a integrar o quadro de acionistas, como foi o caso da Camargo Corrêa (Camargo..., 28 maio 1996, p. C1). 
Gráfico 1

Composição acionária da Usiminas após a privatização

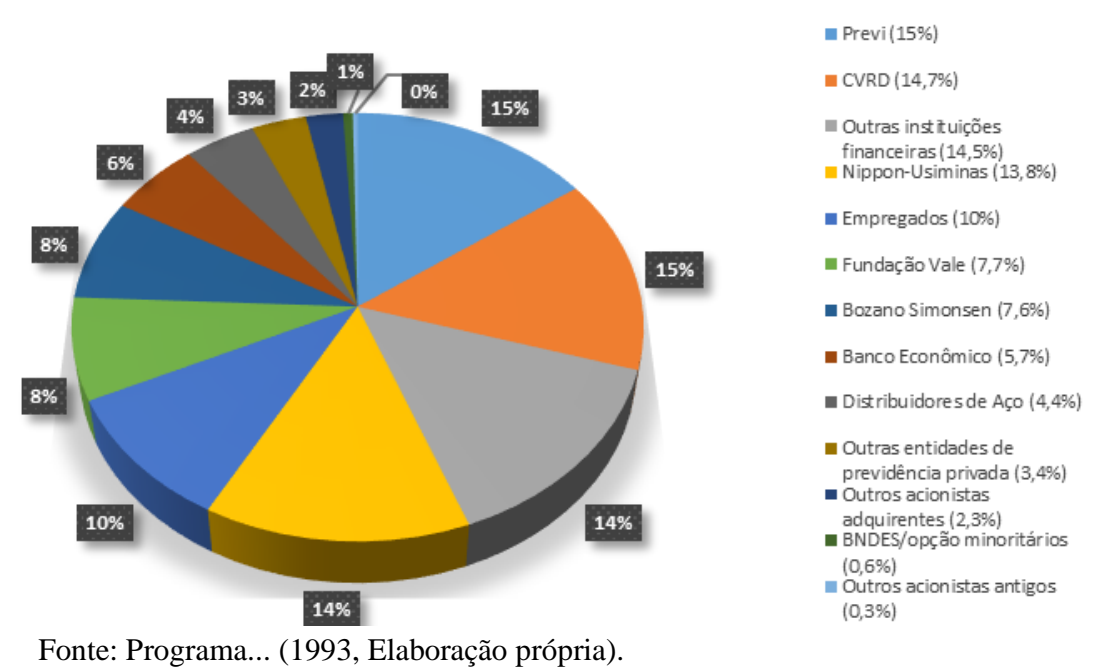

No Gráfico 1 observa-se a relevante fatia das instituições financeiras na composição do capital da Usiminas após a privatização. Somando os $15 \%$ do fundo de pensão do Banco do Brasil (Previ) com o total adquirido por outras instituições financeiras de $14,5 \%$, mais a participação do banco Bozano, Simonsen de 7,6\%, do Banco Econômico, de 5,7\%, e ainda a fatia de outras entidades de previdência privada, de 3,4\%, chegava-se a uma participação de 46,2\% dos negócios.

A Usiminas foi só o começo da participação do Bozano, Simonsen nas privatizações dos anos 1990. Posteriormente, ele entrará no capital de outras empresas desestatizadas, como Embraer, Escelsa e CST. O banco tinha entre seus sócios Julio Bozano e o ex-ministro do planejamento do governo João Figueiredo, ex-ministro da Fazenda do governo Ernesto Geisel e ex-presidente do Banco Central no governo Castelo Branco, Mario Henrique Simonsen ${ }^{17}$.

A privatização da Usiminas também mostrou o aumento da presença de capital estrangeiro, especialmente o japonês, a partir da Nippon ${ }^{18}$-Usiminas, que passou a deter uma fatia de 13,8\% na nova composição acionária. A desnacionalização da empresa, no entanto, não ocorria apenas por meio da participação acionária de estrangeiros como também por contratos internacionais de compra de tecnologia, que foram firmados ao longo dos anos subsequentes à sua venda. Em 1993, por exemplo, a Usiminas iniciou investimentos na reforma

(17) Para se ter uma ideia do tamanho que o banco atingiria com as privatizações, em 1996 ele já atuava em 40 empresas, desde setor agrícola, como café e laranja, à infraestrutura como energia, siderurgia, além da área mineral, de fertilizantes e imobiliária (Grupo..., 25 abr. 1996, C1).

(18) Nippon Steel Corp. é uma multinacional japonesa, maior produtora mundial de aço líquido (A Usiminas..., 8 set. 1997, p. A1; C4). 
Desnacionalização e financeirização: um estudo sobre as privatizações brasileiras...

e substituição de equipamentos que até 1995 somariam US\$ 78 milhões, com compras provenientes principalmente de empresas japonesas (Aumentam..., 6 ago. 1993, p. 21). Também em 1993, assinou contrato com a Toshiba Corporation Ltda. para projeto, fabricação e instalação de novo sistema de acionamento do seu laminador a quente (Usiminas..., 27, 28 e 29 nov. 1993, p. 30). Em 1995 acordou com a japonesa Mitsui \& Co. uma compra de equipamentos (Usiminas..., 13, 14 e 15 out. 1995, p. C2). E em 1998 realizou os trabalhos de montagem de uma nova unidade com a norte-americana Rockwell e a francesa Kvaerner Metals (Nova..., 31 mar. 1998, p. C3).

A sua venda também foi representativa de um processo de concentração e centralização de capitais do setor siderúrgico no Brasil, que seria ampliado com as aquisições que seus novos controladores fariam no país anos depois. Entre elas, ressalta-se a compra da Cosipa em setembro de 1993. Esta negociação envolveu a aquisição de 49,78\% do capital votante da Cosipa, que girava em torno de US\$ 200 milhões, então pertencente à Brastubo (Cícero..., 2 set. 1993, p. 23). Em 1993, os controladores da Usiminas compraram ainda $60 \%$ do capital da Rio Negro, distribuidora de aços em São Paulo, e também adquiriram metade do capital da Fasal, distribuidora de aço sediada em Minas Gerais (Usiminas..., 11, 12 e 13 dez. 1993, p. 24). Em 1996, a Usiminas comprou 50\% do controle acionário da Brasinca Minas, que possuía uma fábrica de estampados pesados de aço em Pouso Alegre (MG) ${ }^{19}$ (Usiminas..., 23, 24 e 25 ago. 1996, p. C3).

\subsubsection{O caso CST}

A venda da Companhia Siderúrgica de Tubarão (CST), voltada ao mercado externo e responsável pela produção de placas de aço, com sede em Serra (ES), foi outra privatização expressiva em valor (US\$ 347,4 milhões) no governo Collor e elucidativa do movimento de desnacionalização e financeirização do setor siderúrgico. Ela tinha como controladores: Siderbrás/CSN (74,0\%), Kawasaki Steel (13\%), Ilva (13\%) e Companhia Vale do Rio Doce (CVRD) $(0,1 \%)$.

Após leilão, passou a ter como acionistas majoritários os bancos Bozano, Simonsen e Unibanco, com 25,4\% e 20\%, respectivamente, além da CVRD, que aumentou sua participação para $15 \%$ do capital da empresa. Os japoneses da Kawasaki Steel mantiveram 13\%, assim como a Ilva (Gráfico 2).

(19) Outros fatores desse movimento de concentração e centralização de capitais envolveram, em 1992 a tentativa sem sucesso de adquirir a Cia. Aços Especiais Itabira (Acesita). 
Gráfico 2

Composição acionária da CST após a privatização

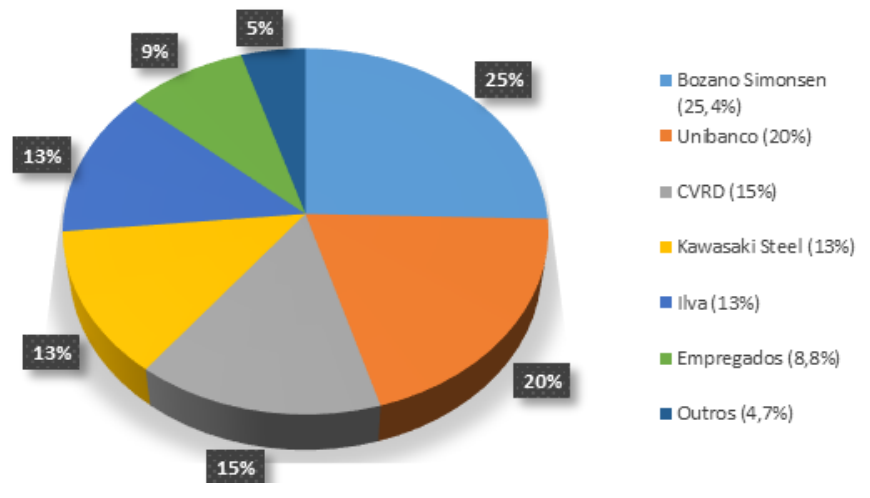

Fonte: Programa... (1993, Elaboração própria).

Os bancos não permaneceram muito tempo com as suas representativas participações. Em 1996, elas foram vendidas, indicando seus objetivos de ganho rápido e especulativo. As ações do Unibanco foram adquiridas em 1996 pela Acesita, que em 1998 passaria a ser controlada pelo grupo francês Usinor. Já as ações ordinárias do Bozano, Simonsen foram vendidas à japonesa Kawasaki (Acesita..., 22 maio 1996, p. C5). Em suma, a saída do Bozano representou um aumento do poder dos japoneses no bloco de controle da empresa enquanto a entrada da Acesita levou à chegada do capital de franceses à empresa.

A saída dos bancos da CST foi bem lucrativa. As ações da empresa haviam se valorizado $211 \%$ desde o leilão. A CST chegou a um valor de mercado (estimado pela cotação de suas ações em bolsa) de US\$ 1,1 bilhão em fevereiro de 1996, apenas quatro anos após sua privatização, quando foi vendida por menos da metade disso ${ }^{20}$ (Bancos..., 26 abr. 1996, p. A1; C3).

A venda das ações desses bancos aos estrangeiros ocorreu dias depois de a CVRD, até então estatal e a terceira maior acionista da CST, renunciar ao direito de preferência na compra das ações ordinárias pertencentes a esses acionistas. A Vale informou à época que considerava alcançada sua estratégia, que era preservar o modelo de controle compartilhado de gestão. A CVRD compartilhava até aquele momento o controle da CST com os outros sócios, como a Kawasaki e os bancos. Assim, sem muita mais explicação, ela informou que manteria sua participação no grupo controlador da CST - com 20,51\% das ações ON - e renunciaria ao

(20) Além da valorização das ações no mercado, deve-se ressaltar que os bancos utilizaram "moedas podres" - aquelas que não tem mais representação do seu valor de face e que dificilmente seriam negociadas no mercado - para a compra de empresas durante as privatizações. Ao usar essas moedas, o seu desembolso efetivo equivaleu à metade do valor da venda. Como justificou o presidente do Conselho de Administração do Unibanco, Roberto Bornhausen, alguns anos depois: o Unibanco havia comprado parte da CST na privatização porque tinha moedas podres e o leilão representava uma boa oportunidade de usá-las, mas não havia intenção de tornar-se um grande participante em empresas fora do setor financeiro (Bancos..., 26 abr. 1996, p. A1; C1). 
Desnacionalização e financeirização: um estudo sobre as privatizações brasileiras...

direito de preferência de aquisição das ações ordinárias que seriam equivalentes a 41,03\% do capital social da CST (Vale..., 30 maio 1996, p. C3; Acesita..., 22 maio 1996, p. C5). Curiosamente, nesta ocasião, deve-se ressaltar que a CVRD renunciava ao controle mais consolidado de uma empresa com faturamento em ascensão, com bons lucros e que já era considerada a maior produtora de aços planos do país. Para se ter uma ideia do tamanho da CST, dois anos após a privatização, seu faturamento chegava perto dos US\$ 700 milhões, uma cifra 1 vez e meia superior ao valor da sua privatização em 1992. O lucro em 1994 somava US\$ 288,6 milhões (Um Ano..., 4, 5 e 6 dez. 1993, p. 28; Lucro 1..., 7 fev. 1995²1).

Ao longo dos anos 1990 e 2000, houve um aprofundamento da desnacionalização do capital da CST a ponto de em 2005 o grupo Arcelor - o maior grupo siderúrgico do mundo, fruto da fusão de Usinor (francesa), Aceralia (italiana) e Arbed (luxemburguesa) -, se tornar o controlador da CST (CSN..., 05, 06 e 07/06/2002, p. C1). Ele ficou em 2005 com 39,9\% das ações ordinárias, $29 \%$ das ações preferenciais, totalizando 33,2\% das ações da CST.

\subsection{Governo Itamar}

O setor siderúrgico brasileiro, em 1993, ano em que esteve à frente da presidência da República Itamar Franco, estava quase completamente privatizado. O governo comemorava este feito e ressaltava a necessidade de "atração, via PND, de capitais privados para atender as necessidades cada vez mais prementes de investimento no setor infra-estrutural, notadamente nos setores de transporte ferroviário e de geração e distribuição de energia elétrica" (Programa..., 1994, p. 6). Itamar daria continuidade ao processo de desestatização iniciado pelo governo anterior e com incentivos maiores ao capital privado. Não por acaso, a Comissão Diretora do PND dizia acreditar "que a ampliação do Programa, seja pela inserção de novas empresas e atividades, seja pela criação de maiores oportunidades de participação de investidores, [propiciaria] condições ainda melhores para tornar a economia mais eficiente e o Estado mais eficaz" (Programa..., 1994, p. 6).

Para alcançar seu objetivo de atrair mais os capitais privados, o governo Itamar, por meio da Medida Provisória n. 362, de 25 de outubro de $1993^{22}$, permitiu a elevação da participação do capital estrangeiro no processo de privatização, que até então era de $40 \%$, para $100 \%$ do total das ações disponíveis em leilões. No governo Itamar foram privatizadas 15 empresas, tendo arrecadado com as vendas US\$ 3,2 bilhões (Tabela 2).

(21) Disponível em: http://www1.folha.uol.com.br/fsp/1995/2/07/dinheiro/21.html.

(22) Disponível em: http://www2.camara.leg.br/legin/fed/medpro/1993/medidaprovisoria-362-25-outubro-1993372883-publicacaooriginal-1-pe.html. 
Tabela 2

Privatizações do Governo Itamar

\begin{tabular}{l|c}
\hline Empresa privatizada & Valor da venda (em US\$ milhões) \\
\hline Companhia Siderúrgica Nacional (CSN) & $1.271,70$ \\
\hline Aço Minas Gerais S.A. (Açominas) & 598,5 \\
\hline Companhia Siderúrgica Paulista (Cosipa) & 359,8 \\
\hline Petroquímica União S.A & 287,53 \\
\hline Ultrafértil - Ind. e Com. de Fertilizantes S/A. & 210,5 \\
\hline Empresa Brasileira de Aeronáutica S.A. (Embraer) & 192,20 \\
\hline Poliolefinas S.A. & 87,1 \\
\hline Oxiteno S.A. Ind. e Com. & 53,9 \\
\hline Politeno Indústria e Comércio S.A. & 44,87 \\
\hline Companhia Pernambucana de Borracha Sintética & 25,95 \\
(Coperbo) & 23,69 \\
\hline Ciquini - Companhia Petroquímica & 16,73 \\
\hline Polialden Petroquímica & 12,14 \\
\hline Acrilonitrila do Nordeste S.A. (Acrinor) & 10,76 \\
\hline Arafértil S.A. & 5,77 \\
\hline Mineração Caraíba Ltda. & $3.201,13$ \\
\hline Total & \\
\hline Fonte: Programa.. (1994, & \\
\hline
\end{tabular}

Fonte: Programa... (1994, 1995, Elaboração própria).

\subsubsection{O caso CSN}

A Companhia Siderúrgica Nacional (CSN) foi a mais expressiva privatização do governo Itamar, correspondendo a US\$ 1,27 bilhão ${ }^{23}$. Ela era "a maior siderúrgica integrada fabricante de produtos planos e aço comum no país” (Programa..., 1994, p. 9). Ela tinha capacidade para produzir 4,6 milhões de toneladas de aço por ano. Seu controle era da Siderbrás/Tesouro (90,8\%). Após leilão, a composição acionária ficou da seguinte forma (Gráfico 3):

De acordo com o Gráfico 3, a CSN foi comprada principalmente pelo grupo denominado "outras instituições financeiras", que respondeu após a privatização por $12,5 \%$ do seu capital - o maior montante entre os novos acionistas. Com a forte penetração das instituições financeiras, após sua venda em abril de 1993, logo houve uma emissão de ADRs ${ }^{24}$ na Bolsa de Nova York autorizada. Em outubro do mesmo ano, seus papéis iniciaram

(23) Sobre o seu valor de venda de US\$1,27 bilhão, deve-se destacar que o governo havia promovido previamente um saneamento financeiro da empresa na ordem de US\$ 756 milhões. Isso significa que do valor arrecadado com a venda, mais da metade já havia sido gasto pelo governo anteriormente.

(24) American Depositary Receipt (ADR) é a denominação de um título de empresa estrangeira cotado em dólar e negociado nos mercados financeiros norte-americanos. 
negociação fora do país. Assim como ocorreu em outros processos de privatização, também foi rápida a reversão dos seus resultados negativos, o que sinalizava que quando foi privatizada já estava pronta para uma grande expansão de produção e para dar lucro. Apenas um ano após sua venda, a empresa apresentava um lucro líquido de US\$ 150 milhões e atingia o recorde latino-americano de produção, com 4,6 milhões de toneladas de aço líquido (CSN..., 29/10/1993, p. 19; CSN..., 18/01/1995, p. 9).

Gráfico 3

Composição acionária da CSN após a privatização

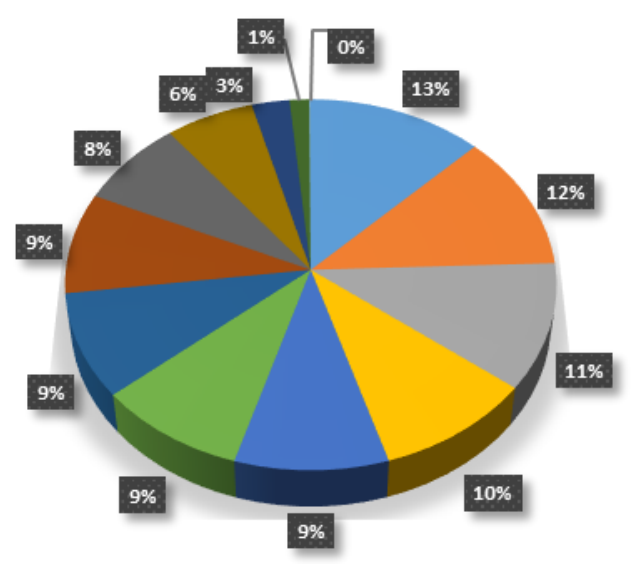

Fonte: Programa... (1994, Elaboração própria).

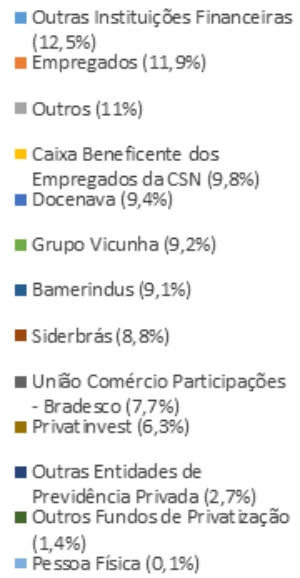

A privatização da CSN, assim como em outros casos, se mostrava um bom negócio para os bancos. O Bamerindus, por exemplo, vendeu sua participação, de 9,1\%, já em dezembro de 1995 aos grupos Vicunha, Bradesco e Previ. O valor inicial pedido pelo banco foi de $\mathrm{R} \$ 500$ milhões, mas o negócio teria sido fechado em $\mathrm{R} \$ 250$ milhões ( $\mathrm{R}$ \$ 500 Milhões..., 8, 9 e 10 dez. 1995, p. A1; B2). O grupo Vicunha, do empresário Benjamin Steinbruch $^{25}$, adquiriu $4 \%$ das ações do Bamerindus, tornando-se o maior acionista da CSN, com 9,2\% das ações ordinárias. O Bradesco adquiriu 2,6\% das ações do Bamerindus e a Previ ficou com 2,5\% (Bamerindus..., 1 dez. 1995, p. 7).

A privatização era tão interessante à concentração e centralização de capitais que os controladores da CSN, anos depois, em 1996, comprariam uma fatia da Light, e em 1997 comprariam a CVRD. Por meio de sua subsidiária, a CSN Steel Corp., sociedade constituída nas Ilhas Cayman, e em parceria com CSN Panamá e alguns fundos de investimentos, o Consórcio Brasil, liderado pela CSN, comprou 41,73\% do capital votante da CVRD e 26,85\% de seu capital social total, por R\$ 3,3 bilhões ${ }^{26}$ (Vale..., 13 maio 1997, p. A3; C5; CSN..., 3 jun. 1996, p. B1).

(25) Steinbruch tinha forte ligação com o filho mais velho de FHC, Paulo Henrique, sendo este funcionário de alto escalão nas empresas de Steinbruch.

(26) A privatização da CVRD será analisada posteriormente. 


\subsubsection{O caso Petroquímica União}

A venda da Petroquímica União S.A. (PQU), com sede em Santo André (SP), alcançou US\$ 287,5 milhões, e foi a mais expressiva venda do setor petroquímico feita por Itamar. Antes da privatização, suas ações estavam divididas entre Petroquisa (67,8\%), Unipar (28,9\%), Banco Indústria e Comércio (1,3\%), Bradesco $(0,8 \%)$, Odebrecht $(0,7 \%)$ e RDN $(0,6 \%)$. Após a desestatização da PQU, as ações dividiram-se conforme Gráfico 4.

Gráfico 4

Composição acionária da Petroquímica União após a privatização

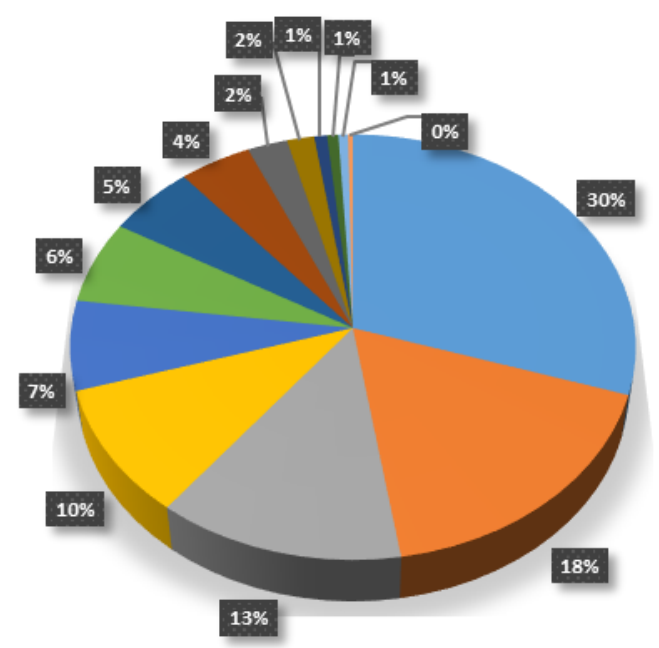

Fonte: Programa... (1995, Elaboração própria).

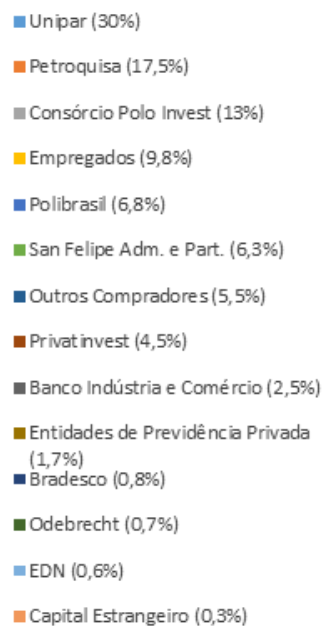

O Gráfico 4 mostra que os três principais acionistas da PQU após o leilão foram: a Unipar (que praticamente manteve a fatia que já possuía, de 30\%); a Petroquisa (empresa da Petrobrás que detinha o controle da PQU e que reduziu sua participação com a privatização, pois foram as suas ações colocadas à venda, e ficou com 17,5\%) e o Consórcio Polo Invest, que ficou com $13 \%$.

Os novos acionistas refletem a desnacionalização do seu capital. O Consórcio Polo Invest foi liderado pela Union Carbide, empresa norte-americana que estava entre os maiores consumidores da nafta da PQU. Além da Union Carbide, eram consumidores da PQU e integraram este consórcio a Oxiteno, a CBE e a Polibrasil, que era composta por Ipiranga, Suzano e Shell (Consórcio..., 24 jan. 1994, p. 1). Algumas instituições financeiras também participaram do leilão da $\mathrm{PQU}$ adquirindo fatias minoritárias para posteriormente negociá-las por meio de acordo com o Consórcio Polo Invest (Depois..., 6 dez.1993, p. 25).

A entrada do capital estrangeiro foi facilitada na PQU. Poucos dias antes do leilão, o edital de desestatização sofreu alterações: a Comissão Diretora do PND corrigiu um artigo no edital que limitava em $40 \%$ do capital votante a participação do capital estrangeiro. Com base 
Desnacionalização e financeirização: um estudo sobre as privatizações brasileiras...

na MP 362, de 25 de outubro de 1993, recentemente publicada, a Comissão permitiu que o capital estrangeiro adquirisse até $100 \%$ do capital votante da petroquímica (Comissão..., 9 nov. 1993, p. 20).

A PQU era a principal indústria de abastecimento de produtos petroquímicos básicos de São Paulo e integrava o grupo das 10 maiores empresas do setor no país. A empresa tinha 1.200 funcionários e vendia sua fabricação, principalmente de propileno, benzeno e etileno, para as indústrias de embalagens, autopeças, tintas, eletrodomésticos, produtos farmacêuticos e têxteis. A PQU por ano faturava cerca de US\$ 400 milhões (Consórcio..., 24 jan. 1994, p. 1).

O leilão da PQU sofreu seis adiamentos. A resistência dos interessados esteve entre os motivos do adiamento porque exigiam uma fórmula por parte do governo para o cálculo do preço da nafta e a garantia de que após a compra não teriam que cobrir o passivo ambiental da empresa, avaliado em US\$ 200 milhões. Esses acertos foram feitos entre o fim de 1993 e o início de 1994, quando a Companhia de Tecnologia de Saneamento Ambiental de São Paulo informou que estaria disposta a discutir com os novos donos o problema ambiental e quando o governo divulgou uma fórmula para o cálculo da nafta que agradou os empresários (Consórcio..., 24 jan. 1994, p. 1).

\subsubsection{O caso Embraer}

A privatização da Empresa Brasileira de Aeronáutica S.A. (Embraer) em 1994 totalizou US\$192,2 milhões e foi uma das mais importantes vendas de Itamar. Localizada em São José dos Campos (SP), a empresa se dedicava "a projetar, construir e comercializar aeronaves e respectivos acessórios componentes e equipamentos, assim como a executar atividades técnicas vinculadas à produção e à manutenção de material aeronáutico" 27 (Programa..., 1995, p. 21). Antes da privatização, as ações da Embraer eram quase todas da União (95,2\%), além do Banco do Brasil $(4,7 \%)$ e outros acionistas prévios $(0,1 \%)$. Após a venda, o controle da empresa ficou dividido conforme Gráfico 5.

De acordo com o Gráfico 5, após a privatização, a União ficou com 20\% da Embraer, a maior fatia. Em seguida, aparece o banco Bozano, Simonsen, com 16,1\%. Os fundos de pensão Previ e Sistel também compraram participação importante, com $9,8 \%$ cada $^{28}$ e outras fundações de previdência privada ficaram com 9,9\%. Para seus $20 \%$ na Embraer, o governo enaltecia a empresa ao ressaltar o "caráter especifico da indústria, com desenvolvimento

(27) A Embraer comandava ainda quatro empresas: "Indústria Aeronáutica Neiva S.A.; Embraer Aircraft Corporation (EAC), na Flórida (Estados Unidos); Embraer Aviation International (EIA), na França; e Órbita Sistemas Aeroespaciais S.A.” (Programa..., 1995, p. 21). Além disso, a Embraer participava como acionista das empresas: "Motortec Indústria Aeronáutica (11\% do capital) e AM-X International Limited (29,7\% do capital), sediada em Londres, com as quais [mantinha] contratos de transferência de tecnologia" (Programa..., 1995, p. 21).

(28) Em 1997, com um aumento de capital de R \$ 230,2 milhões, esse grupo de acionistas majoritários passou a controlar $85,4 \%$ do capital votante da companhia. A operação envolveu conversão de ações preferenciais em ordinárias (Capital..., 8 set. 1997, p. C4). 
tecnológico de elevado padrão, treinamento de mão de obra de altíssima qualificação técnica e científica e potencial de exportação de alto conteúdo tecnológico" (Programa..., 1995, p. 24).

Gráfico 5

Composição acionária da Embraer após a privatização

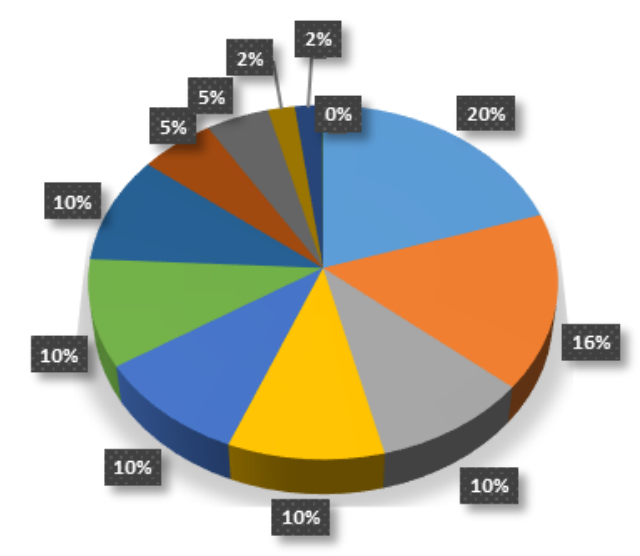

Fonte: Programa... (1995, Elaboração própria).

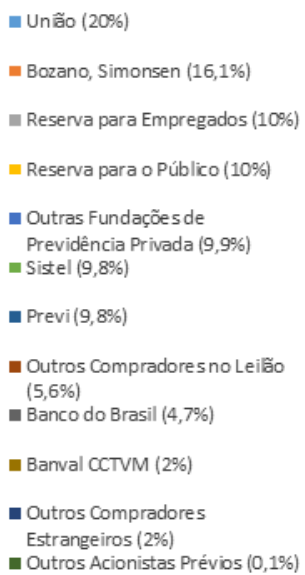

A única explicação que não existia era o porquê da privatização. A Embraer era, de acordo com Biondi (2014, p. 56), "a única indústria aeronáutica - existente em um país menos desenvolvido - fora do circuito dos países ricos, com tradição na área e capaz de roubar mercado das empresas multinacionais no filão que [explorava], isto é, a produção de aviões de porte médio".

Antes da venda, a trajetória da empresa envolveu investimentos voltados à modernização e principalmente ao seu saneamento financeiro. O negócio Embraer era tão rentável que cinco anos depois, em 1999, alguns bancos como o Bozano, Simonsen manifestavam interesse de vender sua participação na companhia, impulsionado pelos lucros que conseguiria na transação (Bozano..., 10 jun. 1999, p. 2).

Em relação ao capital estrangeiro, a privatização da Embraer teve duas denúncias do Sindicato dos Engenheiros de São José dos Campos (SP). A primeira esteve relacionada à entrega de documentos sigilosos pelo presidente da Comissão do PND, André Franco Montoro Filho, a grupos estrangeiros. A segunda era contra o então presidente da Embraer nos EUA, Newton Berwing, e o superintendente Ozires Silva, por participação desses empresários na formação de um grupo de investidores norte-americanos interessados no leilão da Embraer (Denúncia..., 10 jul. 1994, p. 20).

\subsection{Primeiro Governo FHC}

Sob o governo FHC, acentuaram-se as privatizações. Houve leis, decretos e medidas provisórias que não só estenderam as privatizações aos serviços públicos, como também 
Desnacionalização e financeirização: um estudo sobre as privatizações brasileiras...

facilitaram e simplificaram o processo de privatização. A Medida Provisória 841, de janeiro de $1995^{29}$, foi uma das principais. Ela promoveu mudanças na Lei 8.031, de abril de 1990, e criou o Conselho Nacional de Desestatização (CND) em substituição à Comissão Diretora, com o objetivo de conferir "maior agilidade" (Programa..., 1996, p. 35) às privatizações. Além desta, a Lei n. 8.987, de 13 de fevereiro de $1995^{30}$, que estabelecia a lei geral de concessões, e a Lei n. 9.074 , de 7 de julho de $1995^{31}$, que definiu o novo regime de concessões de serviços públicos, foram outros marcos importantes do governo FHC. A Lei 8.987 estabeleceu "o novo regime de concessão e permissão de serviços públicos, aplicável aos setores de energia elétrica e de transportes, este último envolvendo o sistema rodoviário, ferroviário e portuário" (Programa..., 1996, p. 7). E a Lei 9.074 foi "aplicada às concessões dos serviços e obras públicas, em especial os serviços de energia elétrica, viabilizando sua transferência ao setor privado" (Programa..., 1996, p. 7). Além disso, a Lei 8.987 trouxe outra alteração significativa: estender o PND aos Estados e Municípios.

Entre outras mudanças do governo FHC, em 1995 foi enviado ao Congresso Nacional um projeto de lei relacionado ao setor de telecomunicações que regulamentava "a exploração pela iniciativa privada de serviços de telefonia celular e adicionados e de serviços satélites. Foi ainda regulamentada a outorga de serviços de telecomunicações e de radiodifusão e os serviços de TV a cabo" (Programa..., 1996, p. 7). Em 1996 o governo FHC instituiu o Decreto n. 2.077, de 21 de novembro de $1996^{32}$, que promoveu alterações no Decreto n. 1.024, de 29 de julho de $1994^{33}$, permitindo, por meio do Artigo 33, que o CND pudesse "estabelecer procedimentos simplificados para os processos de desestatização, inclusive para a fixação do preço mínimo" com o objetivo de favorecer e acelerar as privatizações. Em setembro de 1997, por sua vez, a Lei $9.491^{34}$ "incorporou vários aprimoramentos e revogou a Lei 8.031, de 12.04.90, que instituiu o PND" (Programa..., 1998, p. 5), para acelerar o processo de desestatização, com a reformulação do I PND. Os objetivos fundamentais do então II PND de 1997 se assemelhavam aos do PND de Collor. Mas, no que dizia respeito às empresas que poderiam ser privatizadas, o II PND incluiu dois tipos de empresas que não faziam parte do PND original: serviços públicos e instituições financeiras públicas estaduais ${ }^{35}$.

(29) Disponível em: http://www2.camara.leg.br/legin/fed/medpro/1995/medidaprovisoria-841-19-janeiro-1995-377369publicacaooriginal-1-pe.html.

(30) Disponível em: http://www2.camara.leg.br/legin/fed/lei/1995/lei-8987-13-fevereiro-1995-349810publicacaooriginal-1-pl.html.

(31) Disponível em: http://www2.camara.leg.br/legin/fed/lei/1995/lei-9074-7-julho-1995-347472-publicacaooriginal-1pl.html.

(32) Disponível em: http://www2.camara.leg.br/legin/fed/decret/1996/decreto-2077-21-novembro-1996-444978publicacaooriginal-1-pe.html.

(33) Disponível em: http://www2.camara.leg.br/legin/fed/decret/1994/decreto-1204-29-julho-1994-449481publicacaooriginal-1-pe.html.

(34) Disponível em: http://www2.camara.leg.br/legin/fed/lei/1997/lei-9491-9-setembro-1997-365396publicacaooriginal-1-pl.html.

(35) Em 1997, também foram criadas para fiscalização e regulamentação dos setores de telecomunicações e energia a Agência Nacional de Telecomunicações (Anatel) e a Agência Nacional de Energia Elétrica (Aneel). 
No primeiro governo FHC foram desestatizadas 31 empresas, incluindo setores como energia, telecomunicações, transporte e mineração, tendo arrecadado US \$ 31,9 bilhões (Tabela $3)$ :

Tabela 3

Privatizações do primeiro governo FHC

\begin{tabular}{|c|c|}
\hline Empresa privatizada & Valor da venda (em US\$ milhões) \\
\hline Sistema Telebrás & $22.000,00$ \\
\hline CVRD & $3.298,90$ \\
\hline Light Serviços de Eletricidade S.A. & $2.356,90$ \\
\hline Rede Ferroviária Federal S.A. Malha Sudeste & 888,9 \\
\hline Centrais Geradoras do Sul do Brasil S.A. (Gerasul) & 879,48 \\
\hline Espírito Santo Centrais Elétricas S.A. (Escelsa) & 399,932 \\
\hline Rede Ferroviária Federal S.A. Malha Centro-Leste & 316,9 \\
\hline Companhia Petroquímica do Nordeste (Copene) & 270,444 \\
\hline $\begin{array}{l}\text { Companhia Docas do Estado de São Paulo (Codesp - } \\
\text { Tecon 1) }\end{array}$ & 251,1 \\
\hline Banco Meridional do Brasil & 240,1 \\
\hline Rede Ferroviária Federal S.A. Malha Sul & 216,6 \\
\hline Salgema Indústrias Químicas S.A. & 139,213 \\
\hline Companhia Petroquímica de Camaçari (CPC) & 99,564 \\
\hline Polibrasil S.A. Ind. e Com. & 99,4 \\
\hline Porto de Sepetiba & 92,96 \\
\hline Polipropileno S.A. & 81,2 \\
\hline Pronor S.A. & 63,452 \\
\hline Rede Ferroviária Federal S.A. Malha Oeste & 62,36 \\
\hline Companhia Brasileira de Poliuretanos (CBP) & 36 \\
\hline Terminal Roll-On Roll-off do Porto de Rio de Janeiro & 31,56 \\
\hline Nitrocarbono S.A. & 29,55 \\
\hline Rede Ferroviária Federal S.A. Malha Tereza Cristina & 18,51 \\
\hline Estireno do Nordeste S.A. & 16,6 \\
\hline Rede Ferroviária Federal S.A. Malha Nordeste & 15,8 \\
\hline Malha Paulista (antiga Fepasa) & 15,8 \\
\hline Cais de Paul & 15,8 \\
\hline Deten Química S.A. & 12,1 \\
\hline Cais de Capuaba & 10,71 \\
\hline Porto de Angra dos Reis & 9,36 \\
\hline Koppol Films S.A. & 3,1 \\
\hline Companhia Química do Recôncavo (CQR) & 1,708 \\
\hline Total & $31.974,0$ \\
\hline
\end{tabular}

Fonte: Programa... (1996, 1997, 1998 e 1999, Elaboração própria). 
Desnacionalização e financeirização: um estudo sobre as privatizações brasileiras...

\subsubsection{O caso Telebrás}

A privatização do Sistema Telebrás ${ }^{36}$ foi a "maior operação de privatização de um bloco de controle já realizada no mundo" (Programa..., 1999, p. 1) e a mais expressiva desestatização em valor feita no primeiro governo FHC. A sua venda somou R \$ 22 bilhões, tendo sido efetuada em julho de 1998 "através de 12 leilões consecutivos na Bolsa de Valores do Rio de Janeiro - BVRJ"'37 (Programa..., 1999, p. 1).

Dos R\$ 22 bilhões pagos pela Telebrás, a maior parte foi proveniente de capital estrangeiro:

Os grupos estrangeiros, principalmente espanhóis e portugueses, dominaram a disputa. Das 12 empresas, 4 foram arrematadas por consórcios de capital externo. Em outras 6, houve associação entre capital nacional e estrangeiro. Somente 2 telefônicas foram arrematadas por grupos exclusivamente nacionais. Sozinhos, os consórcios estrangeiros investiram $\mathrm{R} \$ 8,026$ bilhões, mais que o dobro do total pago pelas empresas compradas exclusivamente por grupos nacionais (R \$ 3,874 bilhões). Associados, capital externo e nacional investiram mais $\mathrm{R} \$ 10,157$ bilhões (Teles..., 30 jul. 1998) ${ }^{38}$.

O capital estrangeiro foi bem tratado pelo governo. Antes do leilão, FHC chegou a viajar para a Europa e fazer propaganda das desestatizações. Dizia convidar as empresas europeias "ao sucesso" e não "ao sacrifício", e as chamava para participar do que ele denominou "projeto de transformação definitiva da economia brasileira em uma economia madura" (FHC..., 19/09/1995, p. A1).

A venda do Sistema Telebrás mostrou uma articulação política em torno de instituições financeiras que ficou conhecida como "escândalo do grampo no BNDES" 39 (Mendonça..., 20 nov. 1998, p. 5; Presidente..., 21 nov. 1998, p. 4; Grampo..., 24 nov. 1998, p. 4; Acervo..., 15 out. $2014^{40}$ ), que resultou em afastamento de pessoas como o ministro das Comunicações, Luiz Carlos Mendonça de Barros, que havia substituído Sérgio Motta (morto em 1998 poucos meses antes da privatização), e de André Lara Resende, então presidente do BNDES, tendo este assumido o cargo no lugar de Mendonça de Barros. Eles foram acusados de improbidade

(36) Para Prado (1994, p. 106), “a Telebrás [...] uma vez liberada de restrições constitucionais, se torna uma das mais atrativas 'mercadorias' ofertadas pelo processo. As experiências latino-americanas evidenciam o elevado interesse dos grupos internacionais por empresas nacionais de comunicações operando em mercados com demanda potencial elevada".

(37) Com esses leilões, foram vendidas "três holding de telefonia fixa, uma de longa distância e oito de telefonia celular" (PROGRAMA..., 1999, p. 1). Além disso, no mesmo ano "foi finalizado o processo de venda das concessões para exploração de Banda B de telefonia celular, com a venda de cinco áreas restantes, para as quais se arrecadou R \$ 3,3 bilhões" (PROGRAMA..., 1999, p. 1).

(38) Disponível em: http://www1.folha.uol.com.br/fsp/brasil/fc30079802.htm.

(39) Para mais informações sobre as privatizações no governo FHC, ver Ribeiro Jr. (2011).

(40) Disponível em: https://www.cartacapital.com.br/politica/acervo-lembrancas-do-governo-fhc-8756.html. 
administrativa por favorecimento de algumas empresas no processo, entre elas o banco Opportunity ${ }^{41}$.

A privatização do sistema público de telefonia do país efetivou-se após investimentos significativos feitos pelo governo. Enquanto ainda estatal, a Telebrás investiu US\$ 4,3 bilhões em 1993, US\$ 4,4 bilhões em 1994, US\$ 4,5 bilhões em 1995 e US\$ 6,5 bilhões em 1996 (Relatório..., 1996) $^{42}$. Em 1995, o governo chegou a anunciar investimentos bastante elevados para os oito anos seguintes: $\mathrm{R} \$ 75$ bilhões (Governo..., 29 nov. 1995, p. B1).

Além dos investimentos prévios, houve um papel bastante ativo do governo por meio do BNDES, que "coordenou" a privatização, deu financiamento ao pagamento das empresas adquirentes (que inclusive podiam parcelar os valores em três vezes) e disponibilizou recursos para investimentos, após concluído o processo de privatização. Em agosto de 1998, o banco informava que além de destinar R \$ 1,2 bilhão ao financiamento da venda do Sistema Telebrás, preparava a generosidade de uma linha especial de crédito para as empresas que foram privatizadas, que envolvia até US\$ 15 bilhões nos então próximos cinco anos - 30\% dos investimentos de US\$ 50 bilhões que estavam previstos para o setor neste mesmo período (BNDES..., 20 ago. 1998, p. 8).

A venda do sistema de telecomunicações recebeu críticas sobre a rapidez ${ }^{43}$ com que o procedimento de tamanho vulto foi feito. Para Biondi (2014, p. 64), a pressa tinha como motivo o fato de que "desde maio de 1998, os banqueiros e investidores internacionais já estavam fugindo, cortando o crédito, do Brasil, e o real caminhava para a desvalorização". Segundo ele, os leilões da Telebrás permitiriam captar dólares e reais e manter "a ilusão do real até a reeleição". Deve-se ressaltar que o déficit em transações correntes em novembro de 1998 atingia 4,4\% do PIB, o maior patamar desde a crise da dívida externa (Déficit..., 28 nov. 1998, p. 8).

Além das facilidades de crédito ao capital estrangeiro, também houve questionamentos sobre o valor de venda de todo o setor de telecomunicações (incluindo a Banda B de telefonia celular), que chegou a ser estimado em $\mathrm{R} \$ 100$ bilhões pelo próprio governo, poucos meses antes do leilão, em julho de 1997 (Telebrás..., 23 jul. 1997, p. B1). No entanto, esse número foi desconsiderado logo depois e o sistema foi avaliado com o preço mínimo de apenas R $\$ 13,5$ bilhões (Telecom..., 10 e 11 jun. 1998, p. B1; Fundações..., 11 jun. 1998, p. B1). As cifras se distanciavam daquilo que havia sido avaliado até mesmo pelo banco Deutsche Morgan

(41) O ministro Luiz Carlos Mendonça de Barros admitiu em depoimento no Senado que tinha preferência pelo consórcio liderado pelo banco Opportunity no leilão da Tele Norte Leste (MENDONÇA..., 20/11/1998, p. 5). Um dos diretores do banco era Pérsio Arida, seu amigo pessoal, um dos formuladores do plano real, ex-ministro do governo FHC, casado com Elena Landau, que foi diretora de desestatização do BNDES entre 1993 e 1996.

(42) Disponível em: http://www.telebras.com.br/inst/wp-content/uploads/2011/03/RA1996.pdf.

(43) O presidente da Telebrás em 1998, Fernando Xavier, chegou a justificar a privatização dizendo que não havia diferença entre trocar um monopólio estatal por um monopólio privado, quando questionado por membros da OAB sobre os problemas no processo. Segundo ele, não havia riscos de trocar um pelo outro (Presidente..., 2 jul. 1998, p. B1). 
Desnacionalização e financeirização: um estudo sobre as privatizações brasileiras...

Grenfell, que citava US\$ 63,7 bilhões o valor "justo" da Telebrás, sem incluir a Banda B (Sistema..., 14 jan. 1998, p. A1; B1).

\subsubsection{O caso Vale do Rio Doce}

A privatização da CVRD em 1997 também foi representativa do processo de desestatização do primeiro governo FHC, embora em valor ela tenha sido bem menor do que o Sistema Telebrás, alcançando apenas US\$ 3,3 bilhões. Com sede em Itabira (MG), a CVRD era a "maior empresa produtora e exportadora de minério de ferro do mundo e a maior produtora de ouro da América Latina" (Programa..., 1998, p. 22). A composição acionária antes de sua desestatização tinha a União como detentora de $75,97 \%$ das ações ordinárias e os acionistas denominados como "outros" com 24,03\% das ações ordinárias. Após leilão, o controle da CVRD passou para o Consórcio Brasil, liderado pela CSN, que criou a sociedade de propósito especial Valepar (Gráfico 6). Entre os acionistas da Valepar estavam fundos de investimentos como a Sweet River, com 9\% de participação, e a Litel, que detinha 39\% (fatia majoritária na Valepar), e era formada por diversos fundos do Banco do Brasil e fundos de pensão de outras instituições, como Funcef, Petros e Fundação Cesp.

Gráfico 6

Composição acionária da CVRD após a privatização
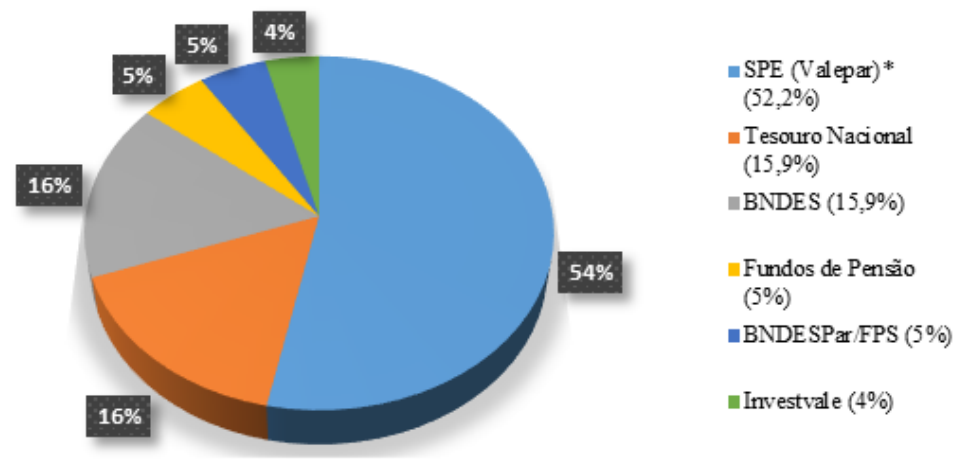

Fonte: Biondi (2014). Elaboração própria.

* Composição da Valepar: Siderúrgica Nacional (25\%); Litel Participações S.A. (39\%); Eletron S.A. (17\%); Sweet River Investiments Ltda. (9\%); BNDESPar (9\%); e Investvale (1\%) - clube de investimentos dos funcionários da Vale.

O valor pago pela CVRD ficou bem distante das avaliações que a empresa recebia. Em 1995, ela chegou a ser avaliada pelo banco Salomon Brothers em quase US\$ 8 bilhões e pelo banco Lehman Brothers, em US\$ 10,4 bilhões (O Ouro..., 7 dez. 1995, p. B3).

A CVRD foi o exemplo mais emblemático de privatização de uma estatal com lucros e receitas altas e uma produção em expansão. A receita líquida da empresa em 1997 era de R \$ 5,2 bilhões e o lucro líquido de R 756 milhões (Demonstrações..., 1997). Antes de ser vendida 
Carlos Henrique Lopes Rodrigues, Vanessa Follmann Jurgenfeld

em maio de 1997, houve vários investimentos na capacidade de produção e diversificação. Entre os planos de investimentos mais importantes, em 1993 a CVRD havia anunciado US\$ 2,7 bilhões para os 5 anos subsequentes (Vale..., 5 fev. 1993, p. 20; Vale...5 fev. 1993, p. 11).

A CVRD era um negócio potente ${ }^{44}$. Ao longo de 1993 até início de 1997, ela fechou joint venture com empresas chinesas para exploração e exportação de minério de ferro e participou de leilões de empresas que estavam sendo desestatizadas de setores correlatos a sua atividade principal (como o leilão da Açominas e da Rede Ferroviária Federal S.A.).

Houve várias liminares contra o leilão da CVRD, mas o governo derrubou todas para garantir a privatização. Na noite anterior ao dia do leilão, em 5 de maio de 1997, por exemplo, o STJ acolheu o pedido do governo de cassação de 23 liminares contrárias à venda (BNDES..., 6 maio 1997, p. A1; B6; B7). Denúncias de irregularidades também foram ignoradas. Em março de 1997, a comissão externa da Câmara que acompanhava a privatização encaminhou ao Tribunal de Contas da União (TCU) um relatório que afirmava que a Merill Lynch, uma das empresas que participaram da modelagem da venda, seria proprietária de uma corretora que operava com um dos candidatos à compra, a mineradora sul-africana Anglo American (Relatório..., 07, 08 e 09 mar. 1997, p. B1).

Embora o ex-presidente do Banco Central Gustavo Franco (O Capital..., 2 fev. 2000, p. 129) justificasse que o governo vendia "empresas estatais caindo aos pedaços", os dados da CVRD explicitavam justamente o contrário. O valor pago pela Vale na desestatização, de US\$ 3,3 bilhões ${ }^{45}$, correspondia a quase um terço do seu patrimônio líquido registrado em 1997 , de $\mathrm{R} \$ 9,4$ bilhões, e era menor do que o faturamento que a empresa teria em 1997, de R\$ 5,4 bilhões ${ }^{46}$.

Corroborando o que os dados da empresa mostravam, antes da privatização, ainda em fevereiro de 1997, o geólogo Francisco F. A. da Costa, ex-presidente da Docegeo, chegou a publicar artigo no Diário do Pará em que dizia que a desestatização tinha relação com a perspectiva de aumento muito elevado de seus lucros em um futuro próximo devido à liquidação da dívida de Carajás e abertura de novas e lucrativas minas de ouro. Isso seria resultante, segundo ele, de uma administração competente sob regime estatal e que seria enganoso o argumento de que tão logo privatizada ela registraria grandes lucros em função da gestão privada da empresa (Privatização..., 23 fev. 2006) ${ }^{47}$.

(44) O negócio CVRD tinha um futuro tão promissor que em 10 anos após a privatização ela chegou a uma receita líquida de US\$ 64 bilhões e a um lucro líquido de US\$ 20 bilhões. Poucos meses antes de ser privatizada, a CVRD encontrou em Carajá reservas de ouro e cobre consideradas uma das mais importantes descobertas geológicas da história. Eram comparáveis com as do início do século XX no Canadá e na África do Sul (Vale...14 jan. 1997, p. B1). Com toda a importância que essa exploração possuía, não houve suspensão do seu leilão, que foi mantido para meses depois, e nem tampouco incluída essa descoberta no preço mínimo fixado para sua desestatização (Biondi, 2014).

(45) Segundo Biondi (2014), o governo brasileiro ainda deixou no caixa da empresa para os compradores R $\$ 700$ milhões. (46) Dados das Demonstrações Financeiras da Vale, disponíveis em www.bovespa.com.br.

(47) Disponível em: http://cartamaior.com.br/?/Coluna/Privatizacao-da-Vale-do-Rio-Doce-insania-ou-negociata/21588. 


\subsubsection{O caso Light}

A venda da Light Serviços de Eletricidade S.A., distribuidora de energia do Rio de Janeiro, atingiu US\$2,36 bilhões e foi a terceira privatização mais importante em valor feita no primeiro mandato de FHC. Antes de sua venda em 1996, a Eletrobrás detinha 81,61\% de suas ações. Após o leilão, ficou evidente a desnacionalização do serviço essencial de energia elétrica (Gráfico 7). A empresa foi arrematada pelo consórcio liderado pela estatal francesa Electricité de France (EDF), associada às norte-americanas Houston Energy Industries, do Texas, e a AES Corporation, de Virginia (EUA). Também fizeram parte do consórcio a CSN e a BNDESPar, mas com fatias minoritárias. O leilão não teve disputa nem ágio. A empresa foi vendida exatamente pelo seu preço mínimo (Light..., 23 maio 1996, p. A1; B4).

A Light era uma empresa estatal cujas receitas operacionais líquidas em 1994, dois anos antes da sua privatização, somavam R \$ 1,3 bilhão. Era uma empresa lucrativa, tendo obtido um lucro líquido de R 127 milhões em 1994 (Programa..., 1997). Em 1996, ano da sua privatização, ela apresentou um lucro líquido ainda maior, de R\$ 173,3 milhões (Comunicado..., 20/02/1997, p. 32). Em 1997, um ano após a sua desestatização, sua receita líquida já atingia R \$ 1,6 bilhão (Estrangeiros..., 1 ago. 1997, p. 21). Seu lucro em 1997 chegava a R\$ 324,3 milhões (Light..., 17 mar. 1998, p. A1; C4).

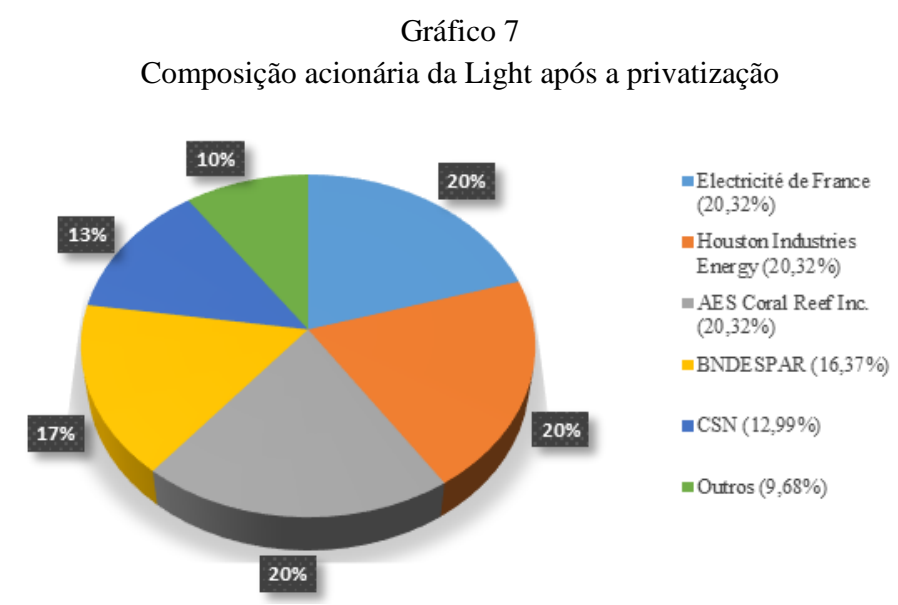

Fonte: Programa... (1997, Elaboração própria).

Após comprar a Light, empresa que chegou a ser considerada a "semi-jóia da coroa"48, a EDF já se empenhava em aumentar sua participação no Brasil, ampliando a concentração e centralização de capitais. A empresa sinalizava a possibilidade de participar do leilão da Cerj, no Rio, o que poderia lhe render o monopólio da distribuição de energia do Estado do Rio de Janeiro (Light..., 21/08/1996, p. A1; B6). Manifestava-se também interessada

(48) Essa declaração foi dada pelo então consultor do banco BBA e um dos mentores do Plano Real, Edmar Bacha (Faltam..., 7, 8, 9 jun. 1996, p. 5). 
Carlos Henrique Lopes Rodrigues, Vanessa Follmann Jurgenfeld

nas distribuidoras de gás do Rio - CEG e Riogás - e também chegou a dizer que tinha interesse na Coelce, no Ceará, mas dela desistiu (Light..., 15/01/1998, p. C5) porque seu foco principal após o Rio de Janeiro foi o Estado de São Paulo, no qual cobiçava a disputa da Companhia Energética de São Paulo (CESP) (Light..., 10 nov. 1997, p. B6).

Mesmo demandando dinheiro público em seu financiamento após a privatização, era dada liberdade de escolha para a tecnologia que seria utilizada pela empresa nos investimentos, podendo trazer equipamentos das matrizes de seus sócios. "Essa concessão trouxe a consequência previsível: as empresas 'privatizadas' passaram a importar maciçamente equipamentos, peças, componentes. 'Quebraram' a indústria nacional. E ‘torraram' dólares, contribuindo para a crise futura do real” (Biondi, 2014, p. 83).

\section{Conclusão}

Com o avanço da internacionalização financeira, os interesses das empresas multinacionais em sua forma de acumulação de capital em países periféricos como o Brasil passaram a ser o da especulação a partir dos títulos da dívida pública e da compra de empresas estatais, vendidas pelo Estado a preços baixos, em áreas estratégicas e com elevadas possibilidades de lucratividade. Além de alterarem os marcos legais para facilitar a atração de capital, principalmente estrangeiro, os governos dos presidentes Collor, Itamar e FHC realizaram políticas de saneamento financeiro das empresas estatais antes que fossem repassadas ao setor privado.

Os leilões revelaram o interesse do capital internacional em setores estratégicos e essenciais para a soberania do país, tanto no ramo de serviços como de exploração de recursos naturais, como energia, telecomunicações e mineração.

Os processos de privatização também explicitaram seu caráter especulativo, dada a grande quantidade de participação de fundos de investimentos e bancos entre os compradores, que aproveitaram o processo para adquirir ações a bons preços e que venderiam facilmente e com alta lucratividade poucos anos depois. Nos mais diversos leilões, ficou evidente a presença de instituições como Previ, bancos Bozano, Simonsen e Opportunity. Este último foi protagonista do maior escândalo de corrupção denunciado à época dos leilões da Telebrás, levando à queda de nomes de confiança do presidente FHC.

\section{Referências bibliográficas}

BATISTA JR., P. N.; RANGEL, A. S. A renegociação da dívida externa brasileira e o Plano Brady: avaliação de alguns dos principais resultados. Caderno Dívida Externa, São Paulo, Pedex, n. 7, 1994.

BATISTA, P. N. B. O Consenso de Washington: a visão neoliberal dos problemas LatinoAmericanos. Caderno Dívida Externa. n. 6, São Paulo, Pedex, 1994. 
Desnacionalização e financeirização: um estudo sobre as privatizações brasileiras...

BIONDI, A. O Brasil privatizado: um balanço do desmonte do Estado. São Paulo: Geração Editorial, 2014.

CAMPOS, F. A. A arte da conquista: o capital internacional no desenvolvimento capitalista brasileiro (1951-1992). Campinas: 2009. Tese (Doutorado)-Instituto de Economia, Universidade Estadual de Campinas.

CANO, W. A desindustrialização no Brasil. Campinas: IE/Unicamp, jan. 2012. (Texto para Discussão, n. 200).

CHESNAIS, F. A globalização e o curso do capitalismo de fim-de-século. Economia e Sociedade, Campinas, Instituto de Economia da Unicamp, n. 5, dez. 1995.

CHESNAIS, F. A mundialização do capital. São Paulo: Xamã, 1996.

DEO, A. A Fiesp e as novas inflexões do capital na década de 1990. Marília: 2005. Dissertação (Mestrado)-Departamento de Ciência Política, Universidade Estadual Paulista Júlio de Mesquita Filho.

FILGUEIRAS, L. A. M. História do Plano Real: fundamentos, impactos e contradições. 3. ed. São Paulo: Boitempo, 2006.

GONÇALVES, R. Globalização e desnacionalização. São Paulo: Paz e Terra, 1999.

HARVEY, D. O novo imperialismo. São Paulo: Edições Loyola, 2003.

OLIVEIRA, G. Brasil Real, desafios da pós-estabilização na virada do milênio. São Paulo: Mandarim, 1996.

PRADO, S. R. Intervenção estatal, privatização e fiscalidade: um estudo sobre a constituição e crise do setor produtivo estatal no Brasil e os processos de privatização a nível mundial. Campinas: 1994. Tese (Doutorado)-Instituto de Economia, Universidade Estadual de Campinas.

RIBEIRO JR. A. A privataria tucana. São Paulo: Geração Editorial, 2011.

SAMPAIO JR., P. A. Globalização e reversão neocolonial: o impasse brasileiro. In: FILOSOFÍA y teorías políticas entre la crítica y la utopia. Buenos Aires: GLACSO, 2007.

SARTI, F. A Internacionalização comercial e produtiva no Mercosul nos anos 90. Campinas: 2001.Tese (Doutorado)-Instituto de Economia, Universidade Estadual de Campinas.

TAVARES, M. C.; MELIN, L. E. Pós-escrito 1997: a reafirmação da hegemonia norteamericana. In: TAVARES, M. C.; FIORI, J. L. (Org.). Poder e dinheiro: uma economia política da globalização. 2. ed. Petrópolis: Vozes, 1997.

\section{Documentos}

FIESP. Livres para crescer: proposta para um Brasil moderno. São Paulo: Cultura Editores Associados, 1990. 
Carlos Henrique Lopes Rodrigues, Vanessa Follmann Jurgenfeld

PRIVATIZAÇÃO a experiência brasileira da BNDESPAR: 1987-1989. Rio de Janeiro: BNDES, 1992.

PROGRAMA Nacional de Desestatização: relatório de atividades. Rio de Janeiro: BNDES, 1991-1999.

\section{Periódicos}

ACESITA e Kawasaki acertam participação no capital da CST. Gazeta Mercantil, Belo Horizonte, p. C5, 22 maio 1996.

AUMENTAM 125\% os lucros da Usiminas. Gazeta Mercantil, Belo Horizonte, p. 1, 6 ago. 1993.

A USIMINAS quer comprar controle da Acesita. Gazeta Mercantil, Rio de Janeiro, p. A1, C4, 8 set. 1997.

USIMINAS registra lucro líquido de US\$ 135 milhões no primeiro semestre. Gazeta Mercantil, Rio de Janeiro, p. 21, 6 ago. 1993.

BANCOS ganham US\$ 500 mi com venda de usinas. Gazeta Mercantil, São Paulo, p. A1; C1, 26 abr. 1996.

BAMERINDUS fecha venda de seu lote na CSN. Folha de São Paulo, Rio de Janeiro, p. 7, 1 dez. 1995.

BNDES tenta vender a Vale ainda hoje. Gazeta Mercantil, Rio de Janeiro, p. A1, B6, B7, 6 maio 1997.

BNDES vai financiar as teles privatizadas. Folha de São Paulo, Brasília, p. 8, 20 ago. 1998.

BOZANO, Simonsen que sair da Embraer. Folha de São Paulo, São Paulo, p. 2, 10 jun. 1999.

CAMARGO Corrêa entra na Usiminas. Gazeta Mercantil, São Paulo, p. C1, 28 maio 1996.

CAPITAL da Embraer passa para R \$ 1,9 bi. Gazeta Mercantil, São José dos Campos, p. C4, 8 set. 1997.

CÍCERO reafirma que Vale e BR estão fora do programa. Gazeta Mercantil, Belo Horizonte, p. 23, 2 set. 1993.

COMISSÃO altera edital e estrangeiros podem adquirir $100 \%$ do capital da PQU. Gazeta Mercantil, Rio de Janeiro, p. 20, 9 nov. 1993.

COMUNICADO de fato relevante da Light. O Globo, Rio de Janeiro, p. 32, 20 fev. 1997.

CONSÓRCIO de empresas recua e participa hoje do leilão da PQU. Folha de São Paulo, Santo André, p. 1, 24 jan. 1994.

CSN confirma que negocia participação acionária com a Corus. Gazeta Mercantil, Rio de Janeiro, p. C1, 5, 6 e 7 jun. 2002. 
Desnacionalização e financeirização: um estudo sobre as privatizações brasileiras...

CSN estima fechar 94 com lucro de US\$ 100 milhões. Gazeta Mercantil, São Paulo, p. 9, 18 jan. 1995.

CSN obtém autorização para lançar ADR em nível 1 nos Estados Unidos. Gazeta Mercantil, Rio de Janeiro, p. 19, 29 out. 1993.

CSN quer comprar a Cerj. Gazeta Mercantil, Rio de Janeiro, p. B1, 3 jun. 1996.

DÉFICIT externo cresce para 4,4\% do PIB. Folha de São Paulo, Brasília, p. 8, 28 nov. 1998.

DENÚNCIA contra edital da empresa. Gazeta Mercantil, São José dos Campos, p. 20, 20 jul. 1994.

DEPOIS de cinco adiamentos, leilão da PQU deve ocorrer na segunda-feira. Gazeta Mercantil, Rio de Janeiro, p. 25, 6 dez. 1993.

ESTRANGEIROS marcam presença no setor elétrico. $O$ Globo, Rio de Janeiro, p. 21, 1 ago. 1997.

FALTAM regras claras para a privatização. Gazeta Mercantil, Foz do Iguaçu, p. 5, 7, 8, 9 jun. 1996.

FHC convida os alemães “ao sucesso”. Gazeta Mercantil, Frankfurt, p. A1, 19 set. 1995.

FUNDAÇÕES articulam-se e procuram bom retorno. Gazeta Mercantil, Rio de Janeiro, p. B1, 10, 11, jun. 1998.

GOVERNO inicia abertura das telecomunicações. O Estado de S. Paulo, Brasília, p. B1, 29 nov. 1995.

GRAMPO derruba irmãos Mendonça de Barros, André Lara Resende e Pio Borges. Folha de São Paulo, Brasília, p. 4, 24 nov. 1998.

GRUPO está presente em 40 empresas de vários setores. Gazeta Mercantil, Rio de Janeiro, p. C1, 25 abr. 1996.

LIGHT quer comprar a Cerj. Gazeta Mercantil, Rio de Janeiro, p. A1; B6, 21 ago. 1996.

LIGHT tem lucro 87\% maior em 1997. Gazeta Mercantil, Rio de Janeiro, p. A1; C4, 17 mar. 1998.

LIGHT terá um novo acordo de acionistas. Gazeta Mercantil, Rio de Janeiro, p. A1; B4, 23 maio 1996.

LIGHT vai disputar Eletropaulo e Cesp. Gazeta Mercantil, Rio de Janeiro, p. B6, 10 nov. 1997.

LIGHT vai investir para evitar cortes de energia. Gazeta Mercantil, Rio de Janeiro, p. C5, 15 jan. 1998.

MENDONÇA diz que preferia consórcio do Opportunity. Folha de São Paulo, Brasília, p. 5, 20 nov. 1998. 
Carlos Henrique Lopes Rodrigues, Vanessa Follmann Jurgenfeld

NOVA unidade de laminação da Usiminas. Gazeta Mercantil, Belo Horizonte, p. C3, 31 mar. 1998.

O CAPITAL estrangeiro. Revista Veja, Editora Abril, Edição 1634, ano 33, n.5, p. 129, 2 fev. 2000 ,

O OURO da Vale é bom negócio. Gazeta Mercantil, Nova York, p. B3, 7 dez. 1995.

PACTUAL negocia ações da Iven. Gazeta Mercantil, Rio de Janeiro, p. C3, 25 nov. 1997.

PRESIDENTE da Telebrás descarta monopólio. Gazeta Mercantil, Brasília, p. B1, 2 jul. 1998.

PRESIDENTE recusa pedido de demissão de ministro. Folha de São Paulo, Brasília, p. 4, 21 nov. 1998.

R\$ 500 MILHÕES entram no Bamerindus. Gazeta Mercantil, São Paulo, p. A1; B2, 8, 9, 10 dez. 1995.

RELATÓRIO da Câmara denuncia irregularidades no processo. Gazeta Mercantil, Brasília, p. B1, 7, 8, 9 mar. 1997.

SISTEMA Telebrás pode valer US\$ 63,7 bi. Gazeta Mercantil, São Paulo, p. B1, 14 jan. 1998.

TELEBRÁS deve ser vendida até junho. Gazeta Mercantil, Brasília, p. B1, 23 jul. 1997.

TELECOM Itália forma consórcio para Telebrás. Gazeta Mercantil, Rio de Janeiro, p. B1, 10, 11 jun. 1998.

UM ano após privatização Siderúrgica de Tubarão volta a ser lucrativa. Gazeta Mercantil, São Paulo, p. 28, 4, 5, 6 dez. 1993.

USIMINAS fecha contrato no valor de US\$ 25 milhões com a Toshiba Corporation. Gazeta Mercantil, Belo Horizonte, p. 30, 27, 28, 29 nov. 1993.

USIMINAS moderniza-se. Gazeta Mercantil, Belo Horizonte, p. C2, 13, 14, 15 out. 1995.

USIMINAS participa da Brasinca Minas. Gazeta Mercantil, Belo Horizonte, p. C3, 23, 24, 25 ago. 1996.

USIMINAS vai assumir o controle da distribuidora paulista de aço Rio Negro. Gazeta Mercantil, Belo Horizonte, p. 24, 11, 12, 13 dez. 1993.

VALE apresenta ao governo plano de investimentos de US\$ 2,7 bilhões. Gazeta Mercantil, Brasília, p. 11, 5 fev. 1993

VALE do Rio Doce planeja investir US\$ 2,7 bi este ano. O Globo. Brasília, p. 20, 5 fev. 1993. VALE faz descoberta histórica. O Estado de S. Paulo, São Paulo, p. B1, 14 jan. 1997.

VALE tem sinal verde para investir na CST. Gazeta Mercantil, Rio de Janeiro, p. C3, 30 maio 1996.

VALE. Gazeta Mercantil, Rio de Janeiro, p. A3; C5, 13 maio 1997. 